\title{
PERAN ANGGOTA TERHADAP KEBERLANJUTAN KELOMPOK TANI PADI AMRIH LOHJINAWI 1 DESA NGAWEN KECAMATAN NGAWEN KABUPATEN BLORA
}

\section{(The Role Of The Members on Sustainable Group Consolidation of Rice Amrih Lohjinawi 1 Ngawen Village Ngawen District Blora Regency)}

\author{
A. T. Khairunnisa, S. Satmoko, D. Mardiningsih \\ Program Studi S1 Agribisnis \\ Fakultas Peternakan dan Pertanian \\ Universitas Diponegoro, Semarang \\ Email: Adilla.Trisna@yahoo.co.id
}

Diterima 08 Mei 2018, disetujui 30 Juli 2018

\begin{abstract}
ABSTRAK
Tujuan penelitian adalah untuk mengetahui pengaruh peran anggota (task roles, maintenance roles, blocking roles) terhadap keberlanjutan kelompok tani padi (kohesivitas, interdependensi, komitmen, program kerja). Penelitian dilaksanakan pada bulan Maret sampai April 2017 di Kelompok Tani Amrih Lohjinawi 1 Desa Ngawen, Kecamatan Ngawen, Kabupaten Blora. Metode yang digunakan dalam penelitian adalah survei. Lokasi penelitian ditentukan secara purposive dengan kriteria kelompok tani yang paling dinamis diantara 28 kelompok tani lainya yang ada di Kecamatan Ngawen. Kelompok tani yang dinamis yaitu kelompok yang sering mengadakan kegiatan guna meningkatkan efektivitas dalam kelompok agar tujuan yang diharapkan tercapai. Pengambilan sampel adalah dengan menggunakan metode simple random sampling dengan jumlah responden 82 anggota. Teknik analisis data menggunakan teknis analisis regresi linier ganda. Faktor task roles dan maintenance roles secara parsial sangat nyata mempunyai pengaruh, sedangkan blocking roles tidak menunjukkan pengaruh terhadap kelanjutan kelompok tani. Namun secara keseluruhan ketiga variabel tersebut mempengaruhi.
\end{abstract}

Kata Kunci : keberlanjutan kelompok, peran anggota

\begin{abstract}
The purpose of this study is to know the influence of member roles (task roles, maintenance roles, blocking roles) on sustainability of rice farmer group (cohesiveness, interdependence, commitment, work program). The study conducted on March until April 2017 in the farmer group Amrih Lohjinawi 1 Ngawen Village, Ngawen District, Blora Regency. The method used in the study was survey. The location of the research is determined by purposive with the most dynamic of farmers groups criteria among 28 others farmer groups in Ngawen District. Sample were taken by using simple random sampling method with total respondents 82 members. Data were analyzed by multiple liniar regression. The results showed that the
\end{abstract}


cohesiveness, commitment, interdependence and work program included into the sustainability category of farmer groups. Factor of task roles and maintenance roles partially very real have influence, while blocking roles do not show influence. But overall all three variables affect.

Keywords: sustainable group consolidation, the role of the members

\section{PENDAHULUAN}

Undang-Undang Nomor 19 Tahun 2013 tentang Perlindungan dan Pemberdayaan Petani, pasal 69 menyatakan bahwa pemerintah dan pemerintah daerah sesuai dengan kewenangannya, berkewajiban mendorong dan memfasilitasi terbentuknya kelembagaan petani dan kelembagaan ekonomi petani. Dalam Pasal 1 dinyatakan pengertian kelembagaan ekonomi petani (KEP) sebagai lembaga yang melaksanakan kegiatan usaha tani yang dibentuk oleh, dari dan untuk petani, guna meningkatkan produktivitas dan efisiensi usaha tani, baik yang berbadan hukum maupun yang tidak berbadan hukum, hal ini dapat diartikan bahwa pembentukan kelompok tani merupakan jawaban atas peraturan pemerintah yang mengharuskan petani membuat kelembagaan atau sebuah kelompok guna memudahkan pemerintah untuk menyalurkan bantuan bagi kelompok tani. PT Pupuk Indonesia (Persero) menegaskan bahwa pupuk bersubsidi hanya untuk petani yang tergabung dengan kelompok tani. Hal ini sesuai dengan Peraturan Mentri Pertanian Nomor 47 Tahun 2017 tentang Alokasi dan Harga Eceran Tertinggi Pupuk Bersubsidi.

Kelompok merupakan sekumpulan orang yang berinteraksi satu sama lain secara relatif (tetap), yang memiliki kepentingan yang sama, sifat atau tujuan dan saling ketergantungan satu dengan yang lainnya dengan memiliki ikatan yang kuat (Adjid, 2001). Ketua kelompok beserta anggotanya merupakan komponen penting tergantung pada ukuran, fungsi dari kelompok tersebut (Stockbridge et al., 2003).

Di dalam konteks pertanian keberlanjutan pada dasarnya kemampuan untuk terus produktif serta tetap mempertahankan basis sumber daya. kelompok dapat bubar sewaktu-waktu, tapi terdapat kelompok yang sulit untuk bubar yaitu kelompok keluarga (trah), masalahnya adalah bagaimana kelompok berkembang mulai dari terbentuk hingga bubarnya (Walgito, 2010)

Didalam keefektifan sebuah kelompok terdapat karakteristik peran anggota yang berbeda (Umstot, 1998). Peran anggota kelompok yang paling utama adalah peran task roles yang berhubungan dengan penyelesaian pekerjaan, Maintenance Roles yang berkaitan dengan menjaga hubungan interpersonal dalam suatu kelompok, selain itu terdapat beberapa peran yang bertentangan dengan tujuan kelompok yaitu Blocking Roles.

Tujuan dari penelitian ini adalah untuk menganalisis pengaruh peran anggota terhadap keberlanjutan kelompok tani. Manfaat dari penelitian ini adalah sebagai referensi bagi petani dalam pengelolaan organisasi yang lebih efisien. Referensi bagi pemerintah dan dinas pertanian terkait dalam menentukan kebijakan pembangunan sektor pertanian. Selain itu, dapat digunakan sebagai bahan referensi bagi penelitian selanjutnya pada bidang yang sama.

\section{METODE PENELITIAN}

Metode yang digunakan dalam penelitian adalah metode penelitian survei. Penelitian dilaksanakan pada bulan Maret sampai April 2017. Penelitian dilakukan di Desa Ngawen Kecamatan Ngawen Kabupaten Blora. Lokasi penelitian ditentukan secara purposive dengan kriteria kelompok tani yang paling dinamis yaitu di Kecamatan Ngawen Kabupaten Blora dengan pertimbangan merupakan kelompok tani yang paling dinamis diantara 28 kelompok tani lainya lalu terpilih kelompok 
tani pada Desa Ngawen yang berada di Kecamatan Ngawen.

Metode yang digunakan dalam pengambilan sampel adalah menggunakan metode simple random sampling adalah pengambilan anggota sampel dari populasi yang dilakukan secara acak tanpa memperhatikan strata yang ada dalam populasi itu (Sugiyono, 2012). Responden dalam penelitian ini adalah 82 anggota dari 104 anggota kelompok tani, setiap anggota populasi mempunyai peluang yang sama untuk diambil menjadi sampel. Sampel yang diambil terdiri dari masyarakat Desa Ngawen yang memiliki lahan pertanian. Penentuan jumlah sampel dihitung dengan cara perhitungan statistik yaitu menggunakan rumus Slovin dengan tingkat presisi yang ditetapkan dalam penentuan sampel adalah $5 \%$.

\section{Hipotesis}

a. Diduga secara serempak peran anggota kelompok (task roles, maintenance roles dan blocking roles) berpengaruh terhadap keberlanjutan kelompok.

b. Diduga secara parsial peran anggota kelompok (task roles, maintenance roles dan blocking roles) berpengaruh terhadap keberlanjutan kelompok.

Data yang dikumpulkan dalam penelitian ini terdiri dari data primer dan data sekunder. Data primer dikumpulkan langsung dari responden dan informan yang diperoleh dari hasil wawancara dengan menggunakan daftar pertanyaan atau kuesioner yang telah dibuat sebelumnya. Kuesioner pada penelitian menggunakan kuesioner tertutup dan bentuk kuesioner dalam skala likert 1-5 dimana 1 merupakan skor terendah dan 5 merupakan skor tertinggi. $1=$ STS (Sangat Tidak Setuju), $2=\mathrm{TS}$ (Tidak Setuju), $3=\mathrm{N}$ (Netral), $4=$ (Setuju), $5=$ (Sangat Setuju). Data sekunder diperoleh dari sumber-sumber data yang tersedia seperti kantor instansi terkait, internet, biro pusat statistik dan kepustakaan. Data dan informasi kuantitatif dalam penelitian ini dianalisis menggunakan regresi linier berganda.

Analisis regresi linier berganda dapat menjelaskan pengaruh variabel independent meliputi task roles $\left(\mathrm{X}_{1}\right)$, maintenance roles $\left(\mathrm{X}_{2}\right)$ dan blocking roles $\left(\mathrm{X}_{3}\right)$, terhadap keberlanjutan kelompok tani (Y) sebagai variabel dependent, secara statistik persamaannya (Sugiyono, 2012) :

$\mathrm{Y}=\mathrm{a}+\mathrm{b}_{1} \mathrm{X}_{1}+\mathrm{b}_{2} \mathrm{X}_{2}+\mathrm{b}_{3} \mathrm{X}_{3}+\mathrm{e}$

Keterangan :

Y = Keberlanjutan kelompok tani (Skor)

a $\quad=$ Konstanta Regresi

$\mathrm{b}_{1, \ldots, 3}=$ Koefisien Regresi Untuk Variabel

$$
\begin{array}{ll} 
& 1,2,3 \\
X_{1} & =\text { Variabel Task Roles } \text { (Skor) } \\
X_{2} & =\text { Variabel Maintenance roles (Skor) } \\
X_{3} & =\text { Variabel Blocking roles (Skor) }
\end{array}
$$

One-Sample Kolmogorov-Smirnov Test

\begin{tabular}{|ll|r|r|r|r|}
\hline & & \multicolumn{1}{c|}{$\mathrm{x} 1$} & \multicolumn{1}{c|}{$\mathrm{x} 2$} & $\mathrm{x} 3$ & \multicolumn{1}{c|}{$\mathrm{Y}$} \\
\hline $\mathrm{N}$ & & 82 & 82 & 82 & 82 \\
Normal Parameters ${ }^{\mathrm{a}}$ & Mean & 26.09 & 28.95 & 37.10 & $1.0129 \mathrm{E} 2$ \\
& Std. Deviation & 6.058 & 5.079 & 3.825 & $1.68204 \mathrm{E} 1$ \\
& .096 & .096 & .072 & .091 \\
Most Extreme Differences Absolute & .096 & .074 & .065 & .091 \\
& Positive & -.074 & -.096 & -.072 & -.047 \\
& Negative & .867 & .866 & .654 & .823 \\
Kolmogorov-Smirnov Z & & .441 & .441 & .786 & .508 \\
Asymp. Sig. (2-tailed) & & &
\end{tabular}

Kesimpulan : Berdasarkan uji normalitas data menunjukkan nilai signifikansi masing-masing variabel dependen dan independen sebesar $\geq 0,05$ maka data tersebut berdistribusi normal. 


\section{HASIL DAN PEMBAHASAN}

\section{Gambaran Umum}

Kecamatan Ngawen merupakan salah satu kecamatan di Kabupaten Blora, Provinsi Jawa Tengah, Indonesia. Luas wilayah kecamatan ini adalah $100,98 \mathrm{~km}^{2}$ atau 5,55\% luas Kabupaten Blora. Lahan di Kecamatan Ngawen terdiri atas lahan sawah seluas $4.041,3075$ hektar $(40,02 \%)$ dan sisanya lahan bukan sawah sebesar 6.056,8845 hektar $(59,98 \%)$ lahan bukan sawah terbagi atas $28,84 \%$ hutan negara, 20,49\% tegalan, 9,98\% pekarangan, 1,27\% lainya. Lahan sawah yang menggunakan irigasi tehnis, setengah teknis dan sederhana sebanyak 357 hektar merupakan sawah tadah hujan. Kecamatan Ngawen memiliki jumlah sawah yang cukup besar dibandingkan dengan tata guna lahan yang lainya. Sawah pada Kecamatan Ngawen termasuk kedalam kategori sawah tadah hujan, sehingga tanaman pertanian seperti padi hanya dapat dipanen oleh petani 2 kali dalam setahun (karena hanya mengandalkan air hujan sebagai irigasinya).

Kelompok Tani Amrih Lohjinawi 1 merupakan salah satu dari 28 kelompok tani yang ada di Kecamatan Ngawen. Kelompok Tani Amrih Lohjinawi 1 berdiri pada bulan April tahun 2008 dengan jumlah awal berdirinya Kelompok Tani Amrih Lohjinawi 1 yaitu sebanyak 104 petani dan hingga saat ini Kelompok Tani Amrih Lohjinawi 1 tetap memiliki anggota 104 petani dan merupakan gabungan dari beberapa petani yang ada di Desa Ngawen. Lokasi Kelompok Tani Amrih Lohjinawi 1 ini berada di Desa Ngawen RT 03 RW 03, Kecamatan Ngawen, Kabupaten Blora. Komoditas dari Kelompok Tani Amrih Lohjinawi 1 adalah padi sawah. Semua anggota yang ada di kelompok tani merupakan petani padi sawah yang ada di Desa Ngawen.

Kelompok Tani Amrih Lohjinawi 1 mendapatkan subsidi dari pemerintah salah satunya yang berupa PUAP (Pengembangan Usaha Agribisnis Pedesaan) peran dari saprodi bidang perencanaan sangat berpengaruh karena kegiatan yang akan dilaksanakan telah diolah dapat terwujud, dari pengumpulan informasi, pengumpulan syarat untuk mengajukan subsidi hingga pengajuan subsidi kepihak yang berwenang. Kelompok Tani Amrih Lohjinawi 1 ini mendapatkan Rp 80.000.000,- yang akan dibagikan sesuai dengan luas lahan anggota kelompok yang rata-rata memiliki 0,3 hektar lahan persawahan yang ditaksir satu orang mendapatkan 6 juta untuk modal usahanya, subsidi PUAP ini harus dikembalikan kepada pemerintah sesuai dengan jangka waktu yang telah ditetapkan yaitu 1,5 tahun. Selain PUAP Kelompok Tani Amrih Lohjinawi 1 ini mendapatkan bantuan dari pemerintah yaitu subsidi saprodi (pupuk, pestisida, bibit) dan bantuan biaya olah yaitu bantuan untuk biaya petani yang mengolah lahan dengan biaya Rp 15.000 per orang yang sifatnya tidak dikembalikan kepada pemerintah. Dalam hal ini Task Roles berpengaruh terhadap keberlanjut kelompok karena peran dari saprodi bidang perencanaan berjalan dengan semestinya. Pada tahun 2016 Gapoktan Kecamatan Ngawen mendapatkan subsidi perbaikan jalan setapak untuk persawahan yang ada di Kecamatan Ngawen. Dengan adanya perbaikan jalan setapak diharapkan para petani dipermudah dalam akses panen dan proses produksi karena jalan yang telah diperbaiki mampu mempermudah keluar masuknya transportasi atau alak untuk kepentingan pertanian.

Pemilihan ketua kelompok dipilih secara aklamasi yaitu dengan cara langsung menunjuk seseorang yang dianggap paling berpengalaman, sedangkan untuk sekretaris, bendahara, saprodi, bidang usaha dan perencanaan dipilih atau ditunjuk secara langsung oleh ketua. Keputusan semua kegiatan dan saran-saran atau usul dari anggota diputuskan oleh ketua Kelompok Tani Amrih Lohjinawi 1 di Kelompok Tani Amrih Lohjinawi 1 sudah menjalankan tugasnya dengan baik terbukti dengan adanya pemecahan masalah seperti anggota yang kesulitan menangani hama, aggota yang kurang paham mengenai pemilihan bibit yang 
baik, anggota yang kurang paham menenai pendistribusian beras.

Variabel Maintenance roles (peran pemeliharaan) berpengaruh terhadap keberlanjutan dengan mengacu dari pendapat Umstot (1998) yang menyatakkan bahwa peran pemeliharaan antara lain upaya memelihara sesama anggota agar anggota tetap harmonis demi mencapai tujuan bersama. Keharmonisan pada Kelompok Tani Amrih Lohjinawi 1 bisa dibilang cukup baik karena selama ini hubungan antara ketua kelompok tani dan anggotanya cukup dekat. Ketua dan anggota merupakan tetangga dan mayoritas mereka memiliki hubungan darah satu dengan yang lainya, masalah yang timbul seperti susahnya anggota mengembalikan pinjaman dan susahnya anggota untuk menghadiri rapat dapat teratasi dengan cara ketua memberikan pengertian kepada anggota kelompok untuk saling menjaga amanah yang telah diberikan dan menjaga kekompakan pada kelompok. Hal ini sesuai dengan pendapat Soedarsono (2005) yang menyatakan bahwa suasana kelompok yang baik adalah yang anggotanya merasa saling menerima, saling menghargai, saling mempercayai dan saling bersahabat maka kelompok tersebut akan semakin dinamis.

\section{Identitas Responden Penelitian}

Berdasarkan Tabel 1 dapat diperoleh hasil bahwa sebagian besar responden pada usia produktif yaitu umur 30 sampai 60 tahun sebanyak 78 orang $(89,01 \%)$. Umur dapat mempengaruhi kemampuan fisik seorang petani dalam melangsungkan kegiatan usahatani. Hal tersebut sesuai dengan pendapat Hasyim (2006) yang menyatakan bahwa umur petani merupakan fator yang sangat penting dalam kemampuan kerja para petani dalam melaksanakan usahatani. Tingkat pendidikan responden sudah cukup tinggi, karena sebagian besar telah menylesaikan wajib belajar 9 tahun dengan presentase $57,31 \%$. Dengan terpenuhinya angka pendidikan tersebut Kelompok Tani Amrih Lohjinawi 1 dapat disebut memiliki pendidikan yang layak. Tingkat pendidikan
Tabel 1. Identitas Responden Petani Padi Amrih Lohjinawi 1

\begin{tabular}{lcc}
\hline \hline No $\quad$ Indikator & Jumlah & Persentase \\
\hline & ---orang--- & $---\% 0^{----}$ \\
1. Umur (Tahun) & & \\
30-40 & 10 & 12,19 \\
$41-50$ & 31 & 37,80 \\
51-60 & 32 & 39,02 \\
61-70 & 9 & 1,09 \\
2. Pendidikan & & \\
SD/Sederajat & 14 & 17,07 \\
SMP/Sederajat & 33 & 40,24 \\
SMA/Sederajat & 29 & 35,36 \\
D3/S1/S2 & 6 & 7,31
\end{tabular}

3. Jumlah Tanggungan Keluarga (orang)

$\begin{array}{rrr}\leq 2 & 1 & 1,21 \\ 3-5 & 49 & 59,75 \\ 6-7 & 32 & 39,02\end{array}$

4. Luas Lahan

$\begin{array}{lll}<0,5 \text { ha } & 63 & 76,82 \\ \geq 0,5 \text { ha } & 19 & 23,17\end{array}$

Sumber : Data Primer Penelitian, 2017.

petani akan berpengaruh dalam perilaku petani dalam pengambilan keputusan dan penerapan teknologi.

Responden mempunyai jumlah tanggungan keluarga yang besar sebanyak 3-7 orang yang memiliki presentase $>90 \%$. Jumlah tanggungan keluarga petani harus diperhatikan karena berkaitan dengan pendapatan petani dalam memenuhi kebutuhan. Hal tersebut sesuai pendapat Soekartawi (2003) menyatakan bahwa jumlah tanggungan keluarga berhubungan dengan peningkatan pendapatan keluarga. Rata-rata luas lahan sawah yang dimiliki anggota Kelompok Tani Amrih Lohjinawi 1 seluas 0,3 ha. Dari 82 responden, responden yang memiliki luas lahan $<0,5$ ha sebanyak 63 orang $(76,82 \%)$ jumlah tersebut tergolong kecil untuk memenuhi kebutuhan hidup.

\section{Peran Anggota terhadap keberlanjutan kelompok}

Berdasarkan hasil penelitian terdapat respon yang beragam mengenai variabel peran anggota (task roles, maintenance roles 
Tabel 2. Jumlah Responden Berdasarkan Penilaian Variabel Peran Anggota

\begin{tabular}{lccc}
\hline & Task roles & Blocking roles & Maintenance roles \\
\hline & & ---Jumlah responden--- & \\
Baik & 6 & 47 & 14 \\
Cukup & 59 & 35 & 65 \\
Kurang & 17 & 0 & 4 \\
\hline Jumlah & 82 & 82 & 82 \\
\hline
\end{tabular}

dan blocking roles) di dalam anggota Kelompok Tani Amrih Lohjinawi 1. Hal tersebut dapat di buktikan pada Tabel 2 .

Berdasarkan hasil penelitian, menurut responden Task roles (Peran Tugas) tergolong cukup. Sebagian responden menilai bahwa pembagian tugas masih belum tinggi. Dari pendapat anggota kelompok, pembagian tugas hanya mengandalkan orang-orang tertentu saja. Hal ini dapat dilihat pada jumlah responden yang menilai cukup dan kurang sebesar 76 orang $(92,68 \%)$. Pembagian tugas di dalam Kelompok Tani Amrih Lohjinawi 1 tergolong cukup. Dalam kenyataanya, dari 104 anggota hanya 10 orang yang menjadi pengurus dan sisanya hanya mengikuti perintah yang ada. Kurangnya campur tangan dari anggota lain membuat pengurus merasa mendapatkan beban yang berat karena segala aktifitas yang ada di kelompok hanya menjadi tugas pengurus saja. Sementara itu anggota yang tidak menjadi pengurus merasa dirinya tidak terlalu di butuhkan karena sifatnya hanya anggota. Hal ini sesuai pendapat Rizal dan Pamuji (2015) yang menyatakan bahwa kelompok yang baik adalah ketika anggotanya ikut terlibat dalam kegiatankegiatan kelompok tani seperti penyusunan rencana usaha kelompok, kegiatan penyuluhan dalam kelompok maupun mengenai masalah dalam kelompok tani.

Berdasarkan hasil penelitian, menurut responden Blocking roles (Peran Penghalang) tergolong kurang, nilai skor yang tinggi dapat diartikan bahwa responden menyetujui terdapat Blocking yang rendah di dalam kelompok. Jumlah responden yang memilih baik dan cukup (tidak terdapat blocking) sebanyak 82, sedangkan responden yang menilai terdapat Blocking tidak ada. Keadaan ini dapat diartikan bahwa segala sesuatu yang dapat mengakibatkan konflik di dalam kelompok mampu diatasi dengan baik. Seperti adanya perbedaan sikap dan kepribadian, kurangnya kesadaran anggota untuk mematuhi kesepakatan serta perbedaan pemahaman dapat diselesaikan dengan cara mediasi.

Berdasarkan hasil penelitian, menurut responden, Maintenance Roles (Peran Pemeliharaan) tergolong cukup. Responden menilai bahwa anggoa kelompok mampu menjaga hubungan antar anggota dalam kelompok. Hal ini dapat dilihat pada jumlah dan presentase responden yang menilai cukup dan kurang sebesar 69 orang $(84,13)$. Suasana pada Kelompok Tani Amrih Lohjinawi 1 bisa dibilang cukup baik karena selama ini hubungan dan komunikasi antara ketua kelompok tani dan anggotanya cukup dekat sehingga dapat menjaga kekompakan pada kelompok. Masalah yang timbul seperti susahnya anggota mengembalikan pinjaman dan susahnya anggota untuk menghadiri rapat. Hal ini sesuai dengan pendapat Nurohin dan Ananta (2009) komunikasi merupakan proses penyampaian pikiran atau perasaan seseorang kepada orang lain, pikiran bisa berupa gagasan, informasi, opini dan sebagainya yang muncul dari benaknya.

Berdasarkan Tabel 3, menurut responden, Kohesivitas tergolong cukup. Responden menilai bahwa anggota kelompok memiliki ikatan emosional, akrab, dan solid sehingga tetap bisa mempertahankan anggota dalam kelompok. Hal ini dapat dilihat pada jumlah dan presentase responden yang menilai kurang sebanyak 2 orang dari 104 orang 
Tabel 3. Jumlah Responden Berdasarkan Penilaian Keberlanjutan Kelompok Tani

\begin{tabular}{lcccc}
\hline & Kohesivitas & Komitmen & Interdependensi & Program kerja \\
\hline & & \multicolumn{1}{c}{-- Jumlah responden--- } & \\
Baik & 26 & 25 & 4 & 8 \\
Cukup & 54 & 50 & 57 & 51 \\
Kurang & 2 & 7 & 23 & 23 \\
\hline Jumlah & 82 & 82 & 82 & 82 \\
\hline
\end{tabular}

dengan presentase $2,43 \%$. Adanya keterikatan yang kuat antara anggota satu dengan yang lainya membuat Kelompok Tani Amrih Lohjinawi 1 tetap bertahan pada jumlah anggota semula, yaitu 104 anggota hingga sekarang. Hal ini sesuai dengan pendapat Faturohman (dalam utami dan Purwaningtyastuti 2012) menyatakan bahwa kohesivitas kelompok adalah tingkat sejauh mana kelompok ingin tetap mempertahankan keanggotaanya atau merupakan ukuran seberapa menariknya kelompok ini bagi individu, juga dapat diartikan sebagai rasa tanggung jawab dan rasa senang pada kelompok. Dan diperkuat oleh pendapat Wismanto dan Suharsono (2012) semakin para anggota saling tertarik dan makin sepakat anggota terhadap sasaran dan tujuan kelompok maka makin kohesif kelompoknya.

Berdasarkan hasil penelitian, menurut responden, Komitmen tergolong cukup. Hal ini dapat dilihat pada jumlah dan presentase responden yang menilai kurang hanya sebesar 7 orang dari 104 orang dengan presentase $8,53 \%$. Setiap anggota di dalam Kelompok Tani Amrih Lohjinawi 1 mampu melaksanakan program kerja, mengikuti setiap kegiatan yang diselenggarakan demi tercapainya tujuan bersama yang telah disepakati sebelumya. Anggota kelompok mampu mengkondisikan dirinya dalam keadaan dimana anggota dapat memihak organisasi tersebut serta tujuan-tujuan dan keinginanya untuk mempertahankan keanggotaan dalam organisasi. Hal ini sesuai dengan pendapat Robbins (2008) yang menjelaskan tentang komitmen organisasi yang tinggi berarti memihak organisasi yang merekrut individu tersebut.
Berdasarkan hasil penelitian, menurut responden, Interdependensi tergolong cukup. Responden menilai bahwa interdependensi di dalam kelompok masih belum tinggi, hal itu disebabkan karena anggota kelompok tidak pernah saling membantu dalam permasalahan permodalan atau keuangan melainkan hanya sekedar membantu menyumbangkan tenaga saja itupun tidak secara cuma-cuma melainkan harus memberi upah. Hal ini dapat dilihat pada jumlah dan presentase responden yang menilai baik hanya sebesar 4 orang dengan presentase $4,87 \%$. Di dalam pemeliharaan padi, secara teknis petani hanya mengandalkan tenaga sendiri maupun tenaga yang nantinya akan diberi upah, sedangkan untuk bantuan tenaga yang sifatnya cumacuma tidak pernah didapat dari anggota lain. Hal ini sesuai dengan Ikbar (2007) yang menyatakan bahwa interdependensi adalah hubungan saling ketergantungan yang mana ada kekurangan dari masing-masing orang yang ada di dalamnya hubungan sosial yang yang bersifat kerjasama atau kooperatif untuk mencapai tujuan bersama.

Berdasarkan hasil penelitian, menurut responden, program kerja tergolong cukup. Responden menilai bahwa program kerja masih belum tinggi karena program kerja hanya disusun oleh pengurus tanpa melibatkan seluruh pihak anggota sehingga kurang mewakil kebutuhan kelompok tani lainnya. Hal ini dapat dilihat pada jumlah dan presentase responden yang menilai baik hanya sebesar 8 orang dari 82 responden dengan presentase 9,75\%. Di dalam Kelompok Tani Amrih Lohjinawi 1 semua anggota mengikuti setiap kegiatan maupun program kerja yang diselenggarakan atau 
Tabel 4. Hasil Analisis Regresi Peran Anggota Terhadap Keberlanjutan Kelompok Tani Padi Amrih Lohjinawi 1

\begin{tabular}{lrc}
\hline \hline \multicolumn{1}{c}{ Variabel } & \multicolumn{1}{c}{$\mathrm{B}$} & Signifikansi \\
\hline Constant & 33,862 & \\
Task roles $\left(\mathrm{X}_{1}\right)$ & 0,404 & $0,002^{* *}$ \\
Blocking roles $\left(\mathrm{X}_{2}\right)$ & 0,319 & $0,012^{*}$ \\
Maintenance roles $\left(\mathrm{X}_{3}\right)$ & 0,047 & $0,587^{\mathrm{ns}}$ \\
R-square & 0,424 & \\
F-hitung & 20,881 & 0,000 \\
\hline
\end{tabular}

Sumber : Data Primer Penelitan, 2017.

Keterangan

$* *$ = berpengaruh

$\mathrm{ns}=$ tidak berpengaruh

telah dijadwalkan sebelumnya namun anggota merasa tidak dilibatkan dalam proses perencanaan program kerja. Hal ini memiliki dua sudut pandang yang pertama yaitu dari sudut pandang anggota, pengurus mengadakan rapat yang dihadiri 10 orang saja yang merupakan ketua, sekertaris, bendahara dan saprodi sementara anggota yang lain tidak menghadiri karena mereka merasa tidak dibutuhkan. Sementara itu dari sudut pandang pengurus, seluruh anggota berhak menghadiri rapat yang diselenggarakan untuk membahas program kerja karena ketua kelompok tidak pernah membuat undangan resmi bagi siapa saja yang harus menghadiri rapat sehingga rapat tersebut bersifat terbuka dan siapa saja yang merupakan anggota boleh mengikutinya. Hal ini dapat disimpulkan bahwa komunikasi yang kurang baik di dalam kelompok sehingga mengakibatkan ketidakharmonisan di dalamnya. Hal ini sependapat dengan Puspita (2016) yang menyatakan bahwa kelompok membutuhkan komunikasi untuk menunjang kekompakan dalam suatu kelompok, komunikasi yang baik memungkinkan kita dapat berbagi informasi, pengalaman dan pengetahuan kita terhadap anggota lainya.

\section{Faktor-faktor yang mempengaruhi keberlanjutan kelompok}

Berdasarkan analisis yang telah dilakukan diperoleh hasil koefisien regresi tiap variabel meliputi koefisien regresi Pembagian tugas (Task roles) $\left(\mathrm{X}_{1}\right)$ sebesar 0,404; Pemeliharaan (Maintenance) $\left(\mathrm{X}_{2}\right)$ sebesar 0.319; Penghalang (Blocking roles) $\left(\mathrm{X}_{3}\right)$ sebesar 0,047 . Nilai konstanta yang diperoleh sebesar 33.862; maka model persamaan liniernya sebagai berikut :

$\mathrm{Y}=33,862+1,121 \mathrm{X}_{1}+1,055 \mathrm{X}_{2}-0,206 \mathrm{X}_{3}+\mathrm{e}$

Berdasarkan Tabel 4 diketahui pengaruh peran anggota terhadap keberlanjutan Kelompok Tani Padi Amrih Lohjinawi 1 diperoleh nilai koefisien determinasi $\left(\mathrm{R}^{2}\right)$ sebesar 0,424 berarti $42,4 \%$ variasi keberlanjutan kelompok tani dapat dijelaskan oleh faktor produksi yang dimasukkan dalam model, sedangkan sisanya yaitu $57,6 \%$ dijelaskan oleh faktor lain yang diluar model regresi yang digunakan. Berdasarkan analisis uji $\mathrm{F}$ diperoleh hasil yaitu nilai signifikansi sebesar 0,000 . Nilai signifikansi $\leq 0,05$ hasil tersebut menunjukkan bahwa peran anggota meliputi task roles, maintenance roles dan blocking roles secara serempak berpengaruh terhadap keberlanjutan kelompok tani.

Adanya keinginan untuk menjadi lebih mandiri. Hal ini dibuktikan dengan adanya usaha dari ketua kelompok membimbing anggotanya agar teori yang diberikan penyuluh mampu dilakukan sepenuhnya oleh anggota, perhitungan bisnis atau profit yang ditekankan oleh ketua agar sebaiknya mampu dijalankan anggota dengan baik dan tidak 
mengandalkan subsidi dari pemerintah tetapi lebih melihat ke kebutuhan pasar. Hal ini sesuai dengan pendapat (Satmoko, 2013) yang menyatakan bahwa ketua kelompok dapat memberikan solusi, maupun pengarahan pada anggotanya demi kelancaran kegiatan kelompok.

Berdasarkan analisis uji t diperoleh hasil bahwa variabel peran anggota yang berpengaruh terhadap keberlanjutan kelompok tani yaitu, Task roles dan Maintenance roles. Hal tersebut dilihat dari nilai signifikansi 0,002 dan $0,012(p<0,05)$. Variable peran anggota yang tidak berpengaruh terhadap keberlanjutan kelompok tani adalah adalah Blocking roles dilihat dari nilai signfikansi $\geq 0,05$. Task roles (peran tugas) berpengaruh terhadap keberlanjutan karena peran tugas dapat dimainkan oleh anggota kelompok sesuai dengan pembagian tugas yang telah disepakati sebelumnya. Struktur organisasi di dalam Kelompok Tani Amrih Lohjinawi 1 memiliki pembagian tugas yang jelas dan sesuai dengam kemampuan masing-masing anggota. Hal ini sesuai dengan pendapat Slamet (2001) yang menyatakan bahwa fungsi tugas dilihat berdasarkan ada tidaknya pembagian tugas apakah setiap anggota mampu memahami dengan baik mengenai tugas yang telah diberikan berdasarkan struktur organisasi demi tercapainya tujuan dalam kelompok.

Variabel Blocking roles (Peran penghalang) tidak berpengaruh terhadap keberlanjutan. Tidak terdapat pengaruh penghalang/ blocking yang signifikan di dalam Kelompok Tani Amrih Lohjinawi 1. Adanya perbedaan pendapat, perbedaan pendirian, dan keyakinan, dapat diselesaikan dengan baik secara kekeluargaan dan mediasi yang dilakukan anggota di dalam kelompok guna memecahkan masalah. Adanya konflik seperti susahnya anggota kelompok mengembalikan pinjaman dari pemerintah dapat memicu perkembangan atau bahkan kehancuran di dalam kelompok tani, adanya konflik dapat dikelola sedemikian rupa sehingga memunculkan kedinamisan yang optimal. Lingkungan yang diciptakan dalam Kelompok Tani Amrih Lohjinawi 1 ini diciptakan sedemikian rupa supaya aktivitas yang dijalankan dapat berjalan dengan nyaman dan lancar, didalam pertemuan kelompok anggota merasakan suasana yang permisif dan bebas.

\section{SIMPULAN DAN SARAN}

\section{Simpulan}

a. Variabel Task Roles, Maintenance Roles dan Blocking Roles secara serempak berpengaruh terhadap keberlanjutan kelompok tani.

b. Variabel Task Roles dan Maintenace Roles secara parsial berpengaruh terhadap keberlanjutan kelompok tani. Sedangkan variabel Blocking Roles secara parsial tidak berpengaruh terhadap keberlanjutan kelompok tani.

\section{Saran}

Saran untuk Kelompok Tani Amrih Lohjinawi 1 adalah :

1. Sebaiknya Kelompok tani melakukan pertemuan secara rutin dan meningkatkan teknologi untuk budidaya tanaman.

2. Sebaiknya, penyuluhan dilakukan setiap kali musim tanam supaya kualitas petani meningkat.

3. Diharapkan agar petani selalu mengikuti pertemuan yang sedang berlangsung dan mendengarkan secara seksama agar informasi dapat diterima dengan baik.

\section{DAFTAR PUSTAKA}

Adjid, D. A. 2001. Penyuluhan Pertanian. Yayasan Sinar Tani, Jakarta.

Hasyim, H. 2006. Analisis Hubungan Faktor Sosial Ekonomi Petani Terhadap Program Penyuluhan Pertanian. Penelitian LP Universitas Sumatera Utara, Medan.

Jhonson, D.W. dan Jhonson, F.P. 2000. Joining Together: Group Theory and 
Group Skills. Seventh Edition. Allyn and Bacon, Inc., Tokyo.

Kusumah, W. dan D. Dwitagama. 2011. Mengenal Penelitian Tindakan Kelas Edisi:2. Indeks, Jakarta.

Nurrohim, H. dan Anata, L. 2009. Efektifitas komunikasi dalam organisasi. Jurnal Manajemen. 7(4):1-9.

Rizal, M, dan S. Pamuji. 2015. Tingkat partisipasi petani dalam kelompok tani padi sawah. Jurnal ISSN. 1(2):352-357.

Satmoko, S. 2013. Pengaruh Peran Anggota Terhadap Keberlanjutan Kelompok Usaha Sapi Potong Di Kabupaten Sragen Jawa Tengah. Disertasi. Program Pascasarjana Universitas Gadjah Mada.

Slamet, M. 2001. Kelompok, Organisasi dan Kepemimpinan. Bogor: Program Studi Ilmu Penyuluhan Pembangunan (PPN),
PPs-IPB, Bogor.

Soedarsono, T. 2005. Dinamika Kelompok. Universitas Terbuka Press, Jakarta.

Soekartawi, 2003. Prinsip Ekonomi Pertanian. Rajawali Press. Jakarta.

Stockbridge, M., A. Dorward, dan J.J. Kydd. 2003. Farmer organizations for market access: A briefing paper. Wye Campus, Kent, England: Imperial College, London.

Sugiyono. 2012. Memahami Penelitian Kualitatif. Alfabeta, Bandung.

Wismanto, B dan Suharsono, M. 2012. Kohesivitas kelompok ditinjau dari komitmen terhadap organisasi dan kelompok pekerjaan. Jurnal Kajian Ilmiah Psikologi. 1(2):179-182. 